\title{
Desain Kapal Ro-Ro (Roll on-Roll off) sebagai Sarana Penyeberangan Rute Pelabuhan Benoa - Nusa Penida Bali
}

\author{
Nyoman Artha Wibawa dan Hesty Anita Kurniawati \\ Departemen Teknik Perkapalan, Fakultas Teknologi Kelautan, Institut Teknologi Sepuluh Nopember (ITS) \\ e-mail: tita@na.its.ac.id
}

\begin{abstract}
Abstrak - Berdasarkan Peraturan Presiden Republik Indonesia Nomor 32 Tahun 2011 tentang Master Plan Percepatan dan Perluasan Pembangunan Ekonomi Indonesia (MP3EI) yang digagas oleh Presiden Indonesia Ke-6, di mana pada Perpres tersebut MP3EI bertujuan untuk mengembangkan segala potensi-potensi yang ada pada masing-masing daerah di Indonesia. Bali - Nusa Tenggara menjadi daerah yang menjadi peran utama sebagai pintu gerbang pariwisata dan pendukung pangan Nasional. Hal tersebut juga memiliki tujuan yang sama dengan program Presiden Indonesia saat ini yaitu pemerataan dan pembangunan tiap daerah di Indonesia serta menjadikan Indonesia sebagai poros maritim dunia. Presiden Indonesia saat ini menggagaskan sebuah program yang diberi nama dengan program "Tol Laut" untuk mememeratakan pertumbuhan ekonomi dan pembangunan Indonesia bagian barat dengan Indonesia bagian timur. Untuk mengaplikasikan programprogram tersebut maka dibutuhkan sarana transportasi yang effisien berupa kapal Ro-Ro (Roll on-Roll off) sebagai sarana penyeberangan antar pulau yang bisa mengangkut penumpang, dan kendaraan. Kapal Ro-Ro ini akan berangkat dari Pelabuhan Benoa menuju Pelabuhan Nusa Penida Bali dengan kecepatan 10 knots. Dalam mendesain kapal dilakukan analisis teknis dan juga analisis ekonomis berupa menghiung biaya pembangunan kapal. Kapal yang didesain memiliki ukuran utama Panjang Garis Air (LWL): 45.76 meter, Panjang antar Garis Tegak (LPP): 44 meter, Lebar (B): 8.2 meter, Tinggi (H): 3 meter, dan Sarat (T): 2.5 meter. Dengan ukuran tersebut kapal ini mampu mengangkut penumpang sebanyak 96 orang, 28 sepeda motor, 10 mobil, dan 4 truk. Dengan ukuran dan jumlah muatan tersebut seluruh regulasi dan ketentuan teknis telah terpenuhi. Besar biaya pembangunan kapal adalah sebesar Rp. 12.655.638.149.
\end{abstract}

Kata Kunci-Desain, Kapal Ro-Ro, MP3EI, Rute Benoa Penida, Tol Laut

\section{PENDAHULUAN}

$\mathrm{M}$ ASTER Plan Percepatan dan Perluasan Pembangunan Ekonomi Indonesia (MP3EI) merupakan sistem yang dirancang oleh pemerintah bertujuan untuk membangun ekonomi Indonesia hingga tahun 2025. MP3EI terfokus pada 8 program utama, yaitu pertanian, pertambangan, energi, industri, kelautan, pariwisata, dan telematika, serta pengembangan kawasan strategis. Tiap-tiap daerah mempunyai peranan yang berbeda dalam setiap program. Untuk mewujudkan MP3EI, wilayah Indonesia dibagi dalam beberapa koridor ekonomi. Pembagian ini berdasarkan potensi yang dimiliki oleh masing-masing daerah. Terdapat enam koridor enokomi dan salah satunya adalah Koridor Ekonomi Bali - Nusa Tenggara dengan tema "Pintu Gerbang Pariwisata dan Pendukung Pangan Nasional". Selain program tersebut, terdapat program "Tol Laut" yang telah dibuat oleh pemerintahan di bawah pimpinan Bapak Joko Widodo. Tol Laut ini merupakan konektivitas laut yang efektif berupa adanya kapal yang melayari secara rutin dan terjadwal dari barat sampai ke timur Indonesia. Kedua program tersebut dibuat bertujuan untuk membangun ekonomi Indonesia menjadi lebih baik.

Berdasarkan latar belakang diatas, akan didesain kapal RoRo (Roll on-Roll off) dengan rute Pelabuhan Benoa (Kabupaten Badung) - Pelabuhan Nusa Penida (Kabupaten Klungkung) Bali sebagai sarana penyeberangan dan konektivitas antar pulau. Pemilihan lokasi ini dikarenakan beberapa hal antara lain pertama, Nusa Penida merupakan salah satu destinasi wisata Internasional yang ada di Bali. Berdasarkan data dari Dinas Pariwisata Kabupaten Klungkung, pada tahun 2015 tercatat sebanyak 93.733 wisatawan yang berkunjung ke Nusa Penida. Kedua, Nusa Penida merupakan salah satu penghasil ternak terbesar yang ada di Bali. Sebagian besar mata pencaharian masyarakat Nusa Penida adalah berternak. Terdapat lebih dari 23.000 ekor sapi yang ada di Nusa Penida menjadi potensi besar yang layak dikembangkan. Ketiga, masih terbatasnya kapal yang bisa mengangkut penumpang dan kendaraan ini merupakan kendala untuk menuju ke Nusa Penida. Hal tersebut tentunya dapat mempengaruhi perkembangan pariwisata serta perkembangan ekonomi dan pembangunan yang ada di Nusa Penida.

\section{TINJAUAN PUSTAKA}

\section{A. $M P 3 E I$}

MP3EI merupakan program pemerintah yang diusung oleh Presiden RI ke-6. Melalui program MP3EI, percepatan dan perluasan pembangunan ekonomi akan menempatkan Indonesia sebagai negara maju pada tahun 2025. Dalam MP3EI terdapat enam koridor ekonomi dengan 8 program utama yaitu pertanian, pertambangan, energi, industri, kelautan, pariwisata, dan telematika, serta pengembangan kawasan strategis. Kedelapan program utama tersebut terdiri 
dari 22 kegiatan ekonomi utama. Bali dan Nusa Tenggara menjadi daerah prioritas pengembangan pariwisata [1].

\section{B. Perkembangan MP3EI Koridor Ekonomi Bali - Nusa Tenggara}

Dalam dokumen MP3EI, koridor ekonomi ini memiliki tiga jenis kegiatan ekonomi utama yaitu pariwisata, perikanan, dan peternakan. Dari kegiatan ekonomi utama tersebut terdapat beberapa kendala yang terjadi salah satunya diperlukannya akses coastal shipping dari Jawa menuju Koridor Ekonomi Bali - Nusa Tenggara. Akses tersebut diperlukan sebagai sarana distribusi barang dari Jawa ke Bali - Nusa Tenggara dan begitu juga sebaliknya sehingga memperkuat sistem logistik nasional [1].

\section{Tol Laut}

Tol Laut adalah konektivitas laut yang efektif berupa adanya kapal yang melayari secara rutin dan terjadwal dari bkkk arat sampai ke timur Indonesia. Dalam pengaplikasian Tol Laut wilayah Indonesia dibagi menjadi dua yaitu wilayah depan dan wilayah dalam. Kapal-kapal yang beroperasi di wilayah depan ini adalah merupakan kapal-kapal asing sedangkan di wilayah dalam beroperasi kapal-kapal milik Indonesia baik itu kapal antar pulau, kapal penyebrangan, maupun kapal ikan [2].

\section{Kapal Ro-Ro}

Kapal jenis Ro-Ro adalah kapal yang bisa memuat penumpang ataupun kendaraan yang berjalan masuk kedalam kapal dengan penggeraknya sendiri dan bisa keluar dengan sendiri juga sehingga disebut sebagai kapal Roll On-Roll Off disingkat $R o-R o$. Kapal ini memiliki fungsi mirip jembatan yang bergerak. Namanya jembatan, apapun bisa melewatinya. Untuk layout awal kapal Ro-Ro yang akan didesain bisa dilihat pada gambar 1 di bawah ini.

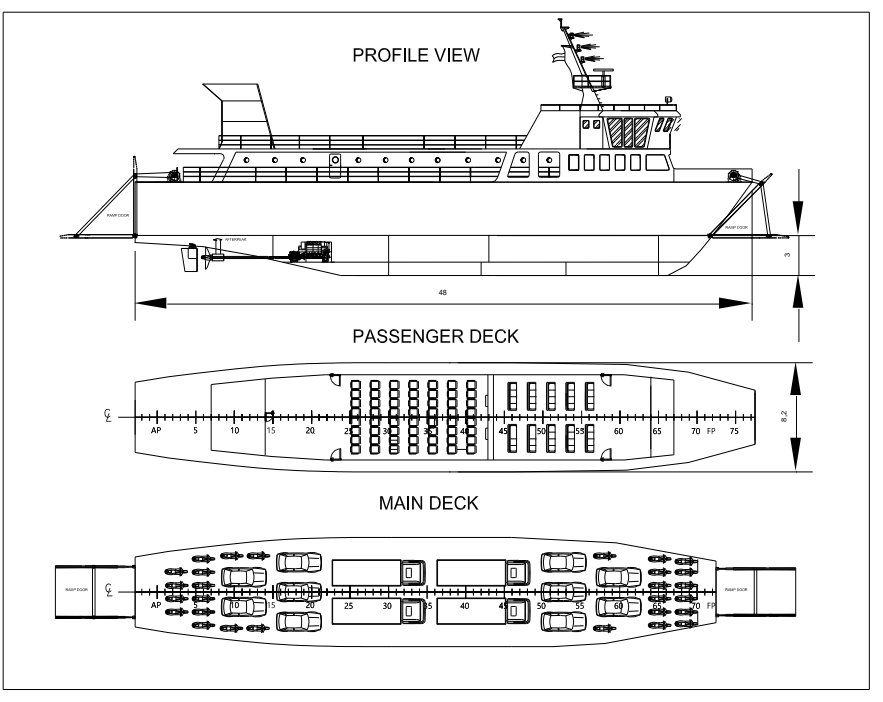

Gambar 1. Layout Awal Kapal.

\section{E. Sistem Lashing}

Sistem Lashing adalah sistem pengikatan kendaraan yang dimuat di atas kapal agar kendaraan tetap pada posisinya pada saat kapal berlayar. Pada Peraturan Menteri Perhubungan 115
Tahun 2016 terdapat aturan mengenai tatacara petunjuk pengamanan (securing) kendaraan di atas kapal. Pengamanan dilakukan minimal dua titik pada setiap sisi roda kendaraan. Dalam Peraturan Menteri Perhubungan Republik Indonesia nomor 115 tahun 2016 kendaraan yang wajib untuk dilakukan pengikatan adalah kendaraan diatas 3.5 ton [3].

\section{F. Pintu Rampa (Ramp Door)}

Pintu rampa (ramp door) adalah pintu yang digunakan sebagai jembatan penghubung antara dermaga dan kapal. Pintu rampa umumnya terletak pada haluan atau buritan kapal, saat merapat di dermaga Pintu rampa akan membuka kebawah. Saat pintu rampa terbuka maka kendaraan dari dermaga bisa masuk ke kapal. Dan pada saat kapal berlayar pintu rampa akan ditutup [4]. Pintu Rampa harus dibuat dengan beberapa ketentuan sebagai berikut:

- Kedap terhadap air laut dalam hal melalui pelayaran laut terbuka

- Kuat menahan beban kendaraan yang melewati pintu saat menaikkan dan menurunkan kendaraan

\section{G. Rute Pelayaran Pelabuhan Benoa - Nusa Penida}

Rute pelayaran Pelabuhan Benoa - Nusa Penida merupakan jalur penyeberangan antara Kabupaten Badung dan Kabupaten Klungkung Bali melalui selat Badung. Penyeberangan antar Kabupaten ini berjarak kurang lebih $41.71 \mathrm{~km}$ dan bisa ditempuh dengan waktu rata-rata selama 60 menit menggunakan kapal penyeberangan dengan kecepatan 10 knot. Berikut gambar 2 merupakan gambar rute pelayaran Pelabuhan Benoa - Nusa Penida.

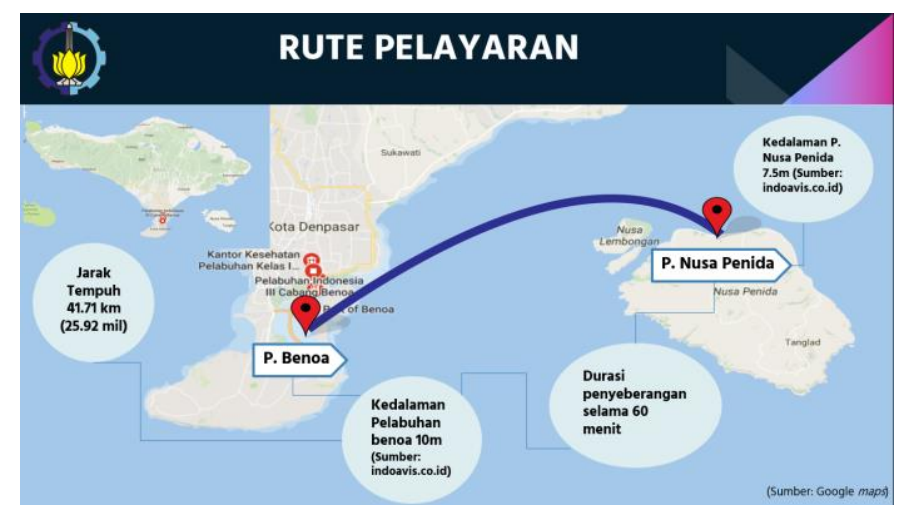

Gambar 2. Rute Pelabuhan Benoa - Nusa Penida.

\section{METODOLOGI}

Dalam penelitian ini terdapat lima tahapan pengerjaan di mana tahap pertama menghasilkan kapasitas muatan kapal, tahap kedua menghasilkan ukuran utama yang telah memenuhi aturan teknis dan regulasi, tahap ketiga menghasilkan rencana garis, tahap keempat menghasilkan rencana umum dan safety plan, dan tahap kelima menghasilkan biaya pembangunan kapal dan estimasi BEP (Break Even Point). Pada beberapa tahap pengerjaan ada pemeriksaan hasil perhitungan berdasarkan kriteria tertentu. Jika hasil pemeriksaan memenuhi maka bisa lanjut ke tahap selanjutnya. Jika tidak memenuhi maka harus dilakukan pengecekan ulang sampai kriteria 
memenuhi. Diagram alir tahapan pengerjaan penelitian dapat dilihat pada Gambar 3 di bawah ini.

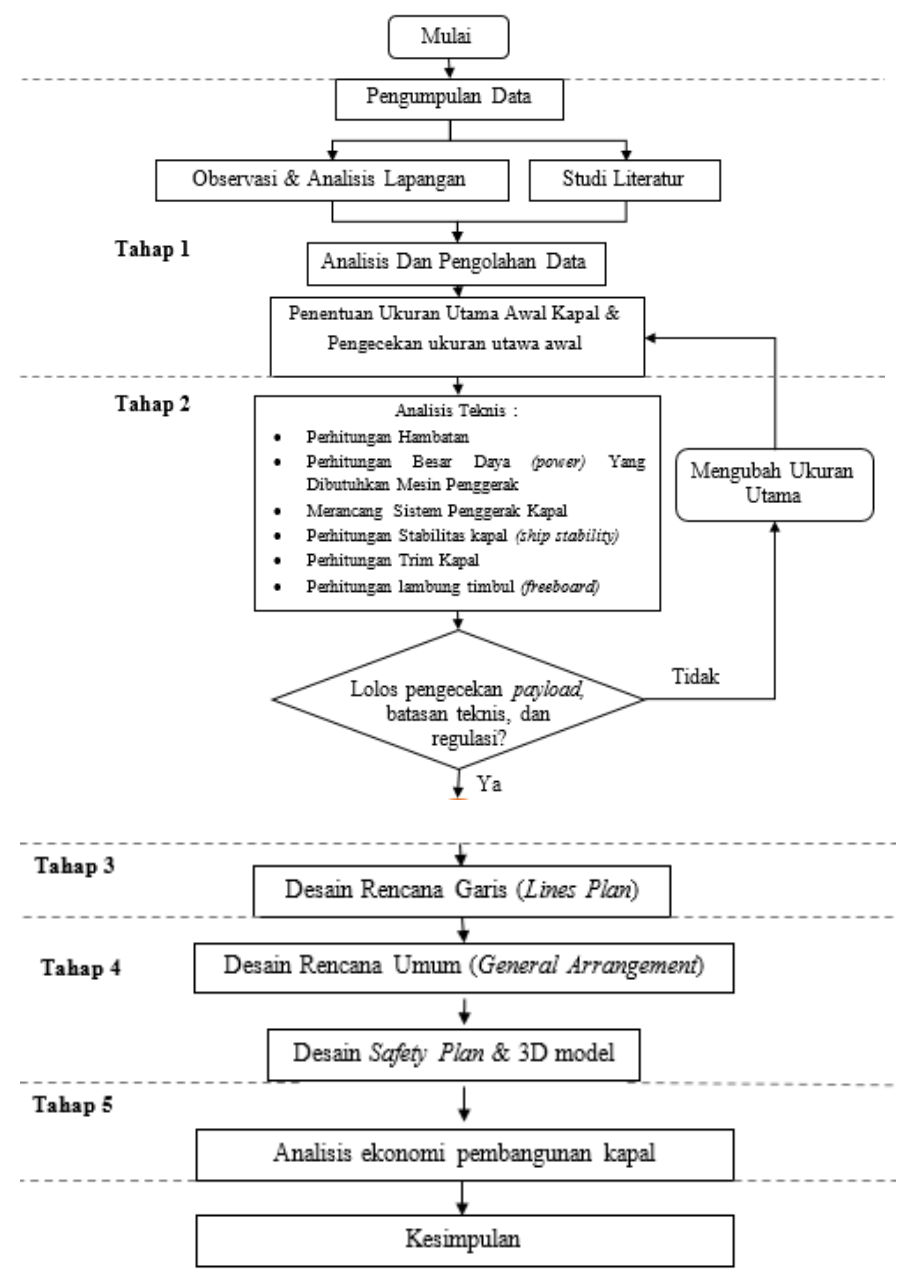

Gambar 3. Diagram Alir Tahap Pengerjaan Penelitian.

\section{ANALISIS TEKNIS}

Dalam pengerjaan penelitian ini terdapat yang pertama dilakukan adalah analisis teknis. Analisis teknis dimulai dari penentuan muatan kapal hingga mendesain $3 D$ Model. Berikut hasil analisis teknis penentuan muatan kapal Ro-Ro berupa jumlah penumpang, kendaraan, dan bagasi yang didapat dari Kantor Kesyahbandaran dan Otoritas Pelabuhan Kelas IV Pelabuhan Padangbai Bali dari tahun 2014 -2016. Karena belum adanya data di tahun 2017, maka dilakukan metode forecasting dengan analisa kurun waktu (time series) dari data yang telah didapat.

Tabel 1.

Jumlah muatan kapal.

\begin{tabular}{lll}
\hline \hline \multicolumn{1}{c}{ Muatan } & \multicolumn{1}{c}{ Jumlah } & \multicolumn{1}{c}{ Berat } \\
\hline Penumpang & 79 orang & 5.925 ton \\
Kendaraan R4 & 14 unit & 165 ton \\
Kendaraan R2 & 28 unit & 5.6 ton \\
Bagasi & 97 unit & 4.85 ton \\
Berat total & & 228.45 ton \\
\hline \hline
\end{tabular}

Selanjutnya adalah penentuan ukuran utama awal kapal, berikut Tabel 2 merupakan nilai ukuran utama awal yang didapat dan telah memenuhi persyaratan.

Tabel 2.

Ukuran utama awal.

\begin{tabular}{lll}
\hline \hline \multicolumn{1}{c}{ Ukuran Utama } & \multicolumn{1}{c}{ Nilai } & \multicolumn{1}{c}{ Satuan } \\
\hline LPP & 44 & meter \\
$\mathrm{B}$ & 8.2 & meter \\
$\mathrm{H}$ & 3 & meter \\
$\mathrm{T}$ & 2.5 & meter \\
\hline \hline
\end{tabular}

Dari ukuran utama tersebut akan dihitung koefisien bentuk badan kapal dan dilanjutkan dengan menghitung hambatan, propulsi kapal sehingga kapasitas mesin induk dapat ditentukan. Mesin yang dipilih dalam mendesain kapal Ro-Ro ini adalah mesin YANMAR tipe 6NY16-UT dengan daya 331 $\mathrm{kW}$. Sedangkan Generator kapal yang digunakan adalah generator merk Volvo dengan daya sebesar $99 \mathrm{~kW}$ sebanyak 2 buah. Berikut Tabel 3 merupakan hasil perhitungan koefisien bentuk badan kapal hingga pemilihan mesin induk dan genset. Tabel 3.

Hasil perhitungan. koefisien bentuk badan kapal hingga pemilihan mesin induk dan gensest.

\begin{tabular}{lll}
\hline \hline & \multicolumn{1}{c}{ Nilai } & \multicolumn{1}{c}{ Keterangan } \\
\hline $\mathrm{C}_{\mathrm{B}}$ & 0.652 & \\
$\mathrm{C}_{\mathrm{P}}$ & 0.664 & \\
$\mathrm{C}_{\mathrm{M}}$ & 0.981 & \\
$\mathrm{C}_{\mathrm{WP}}$ & 0.785 & \\
$\mathrm{LCB}$ & 22.28 & meter dari AP \\
Displ (volume) & 611.58 & $\mathrm{~m}^{3}$ \\
Displ (mass) & 626.87 & $\mathrm{non}$ \\
$\mathrm{R}_{\mathrm{T}}$ & 22.029 & $\mathrm{kN}$ \\
$\mathrm{BHP}$ MCR & 263.256 & $\mathrm{~kW} /$ mesin \\
Daya Mesin & 331 & $\mathrm{~kW} /$ mesin \\
Daya Genset & 99 & $\mathrm{~kW} /$ mesin \\
\hline \hline
\end{tabular}

Dalam analisis teknis, ditentukan pula nilai DWT (Dead Weight Tonnage) dan LWT (Light Weight Tonnage) beserta titik berat dari komponen DWT dan LWT tersebut. Berikut tabel 4 merupakan hasil dari perhitungan DWT dan LWT beserta titk berat dari masing-masing komponen. Berikut Tabel 4 di bawah ini merupakan nilai komponen DWT dan LWT kapal yang akan didesain.

Tabel 4.

DWT dan LWT.

\begin{tabular}{lll}
\hline \hline \multicolumn{1}{c}{ Komponen } & \multicolumn{1}{c}{ Nilai } & \multicolumn{1}{c}{ Keterangan } \\
\hline DWT & 237.149 & ton \\
LWT & 362.138 & ton \\
Koreksi & $3.72 \%$ & Max 10\% (Acc) \\
LCG (DWT) & 3.214 & m dari Midship \\
LCG (LWT) & -0.318 & m dari Midship \\
\hline \hline
\end{tabular}

Kapal Ro-Ro ini merupakan kapal tipe B sehingga perhitungan lambung timbul menggunakan tabel kapal tipe B. Nilai lambung timbul yang didesain harus berinilai lebih besar atau sama dengan dari nilai lambung timbul standar. Berikut Tabel 5 merupakan hasil perhitungan lambung timbul yang telah dilakukan. 
Tabel 5.

Perhitungan lambung timbul.

\begin{tabular}{lll}
\hline \hline & \multicolumn{1}{c}{ Nilai } & Keterangan \\
\hline $\begin{array}{l}\text { Lambung timbul } \\
\text { standar }\end{array}$ & 374 & $\mathrm{~mm}$ \\
$\begin{array}{l}\text { Lambung timbul } \\
\text { desain }\end{array}$ & 800 & $\mathrm{~mm}$ \\
Status & $\begin{array}{l}\text { Nilai desain > nilai } \\
\text { standar }\end{array}$ & Acc \\
\hline \hline
\end{tabular}

Dalam analisis stabilitas, terdapat enam kondisis pelayaran atau load case (LC) yang diberikan. Selain stabilitas, analisis trim juga dilakukan di mana nilai maksimal trim yang diijinkan adalah $\pm 1 \%$ Lpp. Berikut Tabel 6 merupakan hasil analisis stabilitas dari load case 1 sampai load case 6 dan Tabel 8 merupakan hasil analisis trim yang telah dilakukan. Tabel 6.

Hasil analisis stabilitas untuk LC1 - LC6.

\begin{tabular}{|c|c|c|c|c|c|c|c|c|}
\hline \multirow{2}{*}{$\begin{array}{c}\text { IS } \\
\text { Criteria }\end{array}$} & \multirow[t]{2}{*}{ Dizinkan } & \multirow[t]{2}{*}{ Ketentuan } & \multicolumn{6}{|c|}{ Nilai } \\
\hline & & & LC1 & Status & LC2 & Status & LC3 & Status \\
\hline e $0-30^{\circ}$ & 3.151 & $\geq$ & 10.357 & Acc & 8.207 & Acc & 7.3757 & Acc \\
\hline e $0-40^{\circ}$ & 5.157 & $\geq$ & 14.967 & Acc & 11.619 & Acc & 10.337 & Acc \\
\hline e $30-40^{\circ}$ & 1.719 & $\geq$ & 4.609 & Acc & 3.412 & Acc & 2.9611 & Acc \\
\hline $\mathrm{GZ} 30^{\circ}$ & 0.2 & $\geq$ & 0.47 & Acc & 0.349 & Acc & 0.303 & Acc \\
\hline$\Theta \operatorname{Max}$ & 25 & $\geq$ & 29.1 & Acc & 28.2 & Acc & 28.2 & Acc \\
\hline $\mathrm{GM}^{\circ}$ & 0.15 & $\geq$ & 1.925 & Acc & 1.756 & Acc & 1.788 & Acc \\
\hline $\begin{array}{c}\text { Pass } \\
\text { Crowd }\end{array}$ & 10 & $\leq$ & 0 & Acc & 0 & Acc & 0 & Acc \\
\hline $\begin{array}{l}\text { Turning } \\
\text { Angle }\end{array}$ & 10 & $\leq$ & 0 & Acc & 0 & Acc & 0 & Acc \\
\hline IS & Dizinkan & Ketentuan & \multicolumn{6}{|c|}{ Nilai } \\
\hline Criteria & & & LC4 & Status & LC5 & Status & LC6 & Status \\
\hline e $0-30^{\circ}$ & 3.151 & $\geq$ & 10.526 & Acc & 11.066 & Acc & 10.558 & Acc \\
\hline e $0-40^{\circ}$ & 5.157 & $\geq$ & 15.496 & Acc & 16.475 & Acc & 15.557 & Acc \\
\hline $\begin{array}{c}\text { e } 30- \\
40^{\circ}\end{array}$ & 1.719 & $\geq$ & 4.97 & Acc & 5.408 & Acc & 4.998 & Acc \\
\hline $\mathrm{GZ} 30^{\circ}$ & 0.2 & $\geq$ & 0.502 & Acc & 0.548 & Acc & 0.506 & Acc \\
\hline$\theta \operatorname{Max}$ & 25 & $\geq$ & 30.9 & Acc & 30.9 & Acc & 30.9 & Acc \\
\hline $\mathrm{GM}^{\circ}$ & 0.15 & $\geq$ & 1.76 & Acc & 1.74 & Acc & 1.752 & Acc \\
\hline $\begin{array}{c}\text { Pass } \\
\text { Crowd }\end{array}$ & 10 & $\leq$ & 0 & Acc & 0 & Acc & 0 & Acc \\
\hline $\begin{array}{l}\text { Turning } \\
\text { Angle }\end{array}$ & 10 & $\leq$ & 0 & Acc & 0 & Acc & 0 & Acc \\
\hline
\end{tabular}

Tabel 7.

Hasil analisis trim.

\begin{tabular}{|c|c|c|c|c|}
\hline No & Kondisi & Batasan & Nilai & Status \\
\hline 1 & Loadcase 1 & 0.44 & 0.308 & Diterima \\
\hline 2 & Loadcase 2 & 0.44 & 0.353 & Diterima \\
\hline 3 & Loadcase 3 & 0.44 & 0.215 & Diterima \\
\hline 4 & Loadcase 4 & 0.44 & 0.285 & Diterima \\
\hline 5 & Loadcase 5 & 0.44 & 0.311 & Diterima \\
\hline 6 & Loadcase 6 & 0.44 & 0.346 & Diterima \\
\hline
\end{tabular}

Desain rencana garis dapat dilihat pada Lampiran A, desain rencana umum dapat dilihat pada Lampiran B, dan desain $3 D$ Model dapat dilihat pada lampiran C.

\section{ANALISIS EKONOMIS}

Dalam analisis ekonomis ini yang dibahas adalah biaya pembangunan kapal dan perhitungan estimasi Break Even Point (BEP). Dalam menghitung biaya pembangunan kapal, yang dijadikan acuan adalah berat baja total dan harga plat baja di pasaran. Berdasarkan data dari PT. Nicon Steel harga baja per tanggal 1 Juni 2017 adalah sebesar US\$ 714/ton. Dengan harga baja tersebut didapatkan hasil perhitungan biaya pembangunan kapal yang telah dikerjakan dengan mengacu pada pedoman perkiraan biaya dari Direktorat Pengolahan PERTAMINA sebesar Rp. 12,655,638,149.00. Setelah mendapat harga biaya pembangunan kapal, maka didapat BEP terjadi pada tahun kedua tepatnya pada bulan ke 12 dengan biaya operasional kapal tiap tahunnya adalah sebesar Rp. 9,229,528,785 dapat dilihat pada Tabel 8, dan keuntungan bersih sebesar Rp. 696,187,624.04 dapat dilihat pada Tabel 9. Tabel 8.

Biaya Operasional Kapal.

\section{OPERATIONAL COST}

\begin{tabular}{|c|c|c|}
\hline \multicolumn{3}{|c|}{ OPERATIONAL COST } \\
\hline Biaya & Nilai & Masa \\
\hline Cicilan Pinjaman & Rp 3,167,073,447 & per tahun \\
\hline Biaya Perawatan & Rp 4,572,057,600 & per tahun \\
\hline Biaya Asuransi & Rp $\quad 228,602,880$ & per tahun \\
\hline Fresh Water & 377,440 & per tahun \\
\hline Port Charges & $\mathrm{Rp} \quad 174,622,418$ & per tahun \\
\hline Gaji Komplemen & Rp $1,008,000,000$ & per tahun \\
\hline Bahan Bakar Diesel & $\mathrm{Rp} \quad 78,795,000$ & per tahun \\
\hline Total & Rp 9,229,528,785 & per tahun \\
\hline
\end{tabular}

Tabel 9 .

Estimasi Keuntungan Bersih.

\begin{tabular}{|c|lr|}
\hline Item & \multicolumn{2}{|c|}{ Nominal } \\
\hline Biaya Investasi & $\mathrm{Rp}$ & $12,655,638,148.57$ \\
\hline Modal Bank 65\% (Bank Mandiri) & $\mathrm{Rp}$ & $8,226,164,796.57$ \\
\hline Hutang perbulan bunga 13.5\% & $\mathrm{Rp}$ & $18,508,870.79$ \\
\hline Keuntungan kotor & $\mathrm{Rp}$ & $11,430,144,000.00$ \\
\hline Biaya Operasional & $\mathrm{Rp}$ & $9,229,528,785.17$ \\
\hline Biaya Tak terduga 5\% & $\mathrm{Rp}$ & $571,507,200.00$ \\
\hline Pajak penghasilan Usaha 8\% & $\mathrm{Rp}$ & $914,411,520.00$ \\
\hline Keuntungan Bersih & $\mathbf{R p}$ & $\mathbf{6 9 6 , 1 8 7 , 6 2 4 . 0 4}$ \\
\hline
\end{tabular}

\section{KESIMPULAN}

Berdasarkan hasil analisis teknis dan ekonomis yang telah dilakukan, maka dapat ditarik kesimpulan sebagai berikut:

1. Muatan kapal Ro-Ro ini terdiri dari 96 orang penumpang, 4 truk, 10 mobil, dan 28 sepeda motor.

2. Dari hasil analisis teknis yang telah dilakukan maka diperoleh ukuran utama kapal sebagai berikut:

- Length of waterline (LWL) : 45.76 meter

- Length of perpendicular (LPP) : 44 meter

- Breadth (B) : 8.2 meter

- Height $(\mathrm{H}) \quad: 3$ meter

- Draft (T) :2.5 meter

Desain rencana garis dapat dilihat pada Lampiran A sedangkan desain rencana umum dapat dilihat pada Lampiran B.

3. Dari hasil analisis ekonomis yang telah dilakukan biaya pembangunan kapal sebesar Rp. 12,655,638,149.00 dan Break Even Point terjadi pada tahun kedua tepatnya pada bulan ke 19.

4. Desain 3D Model kapal dapat dilihat pada Lampiran C. 
VII. LAMPIRAN

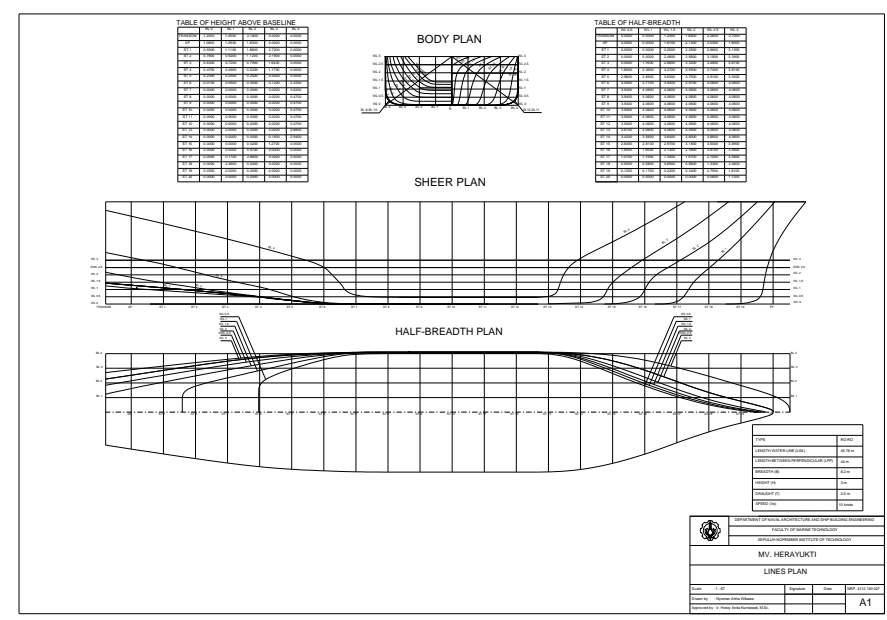

Gambar 4. Desain Rencana Garis

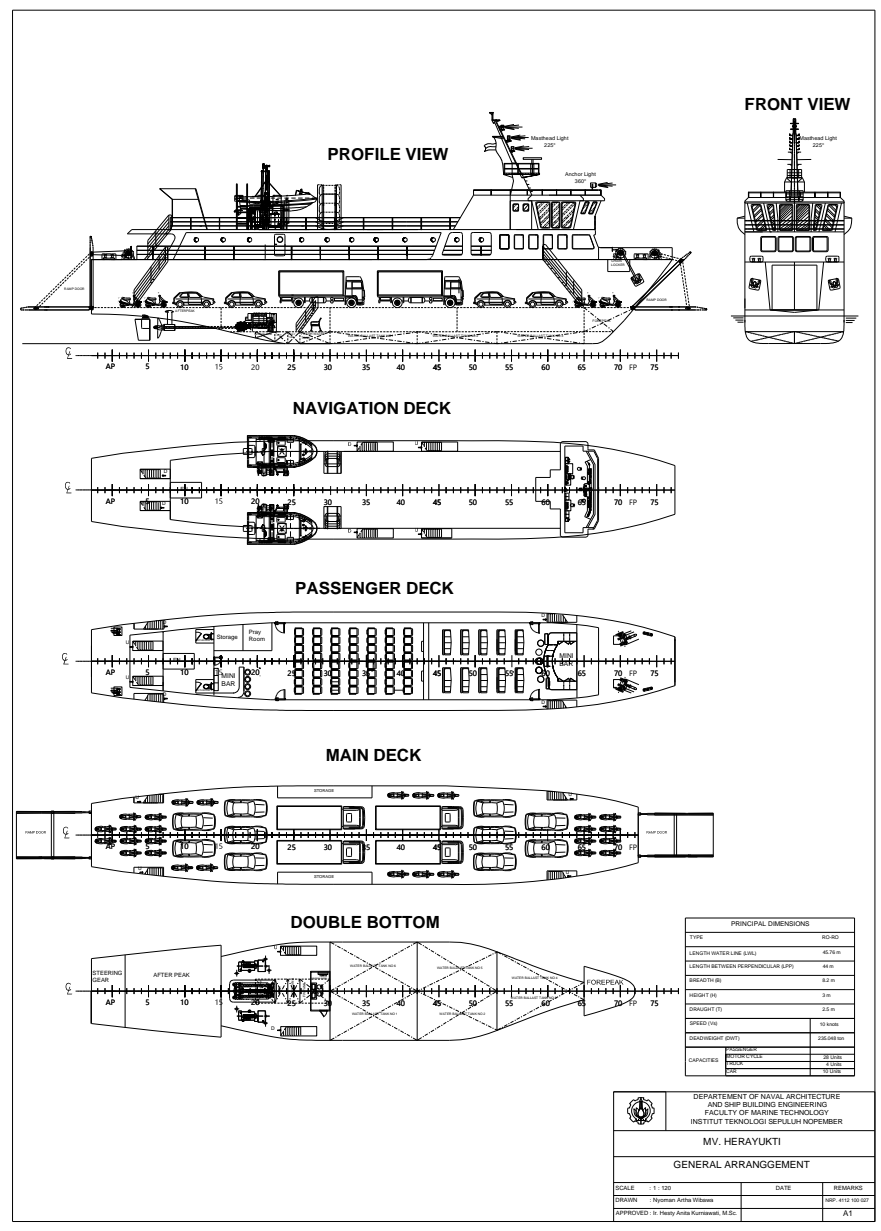

Gambar 5. Desain Rencana Umum
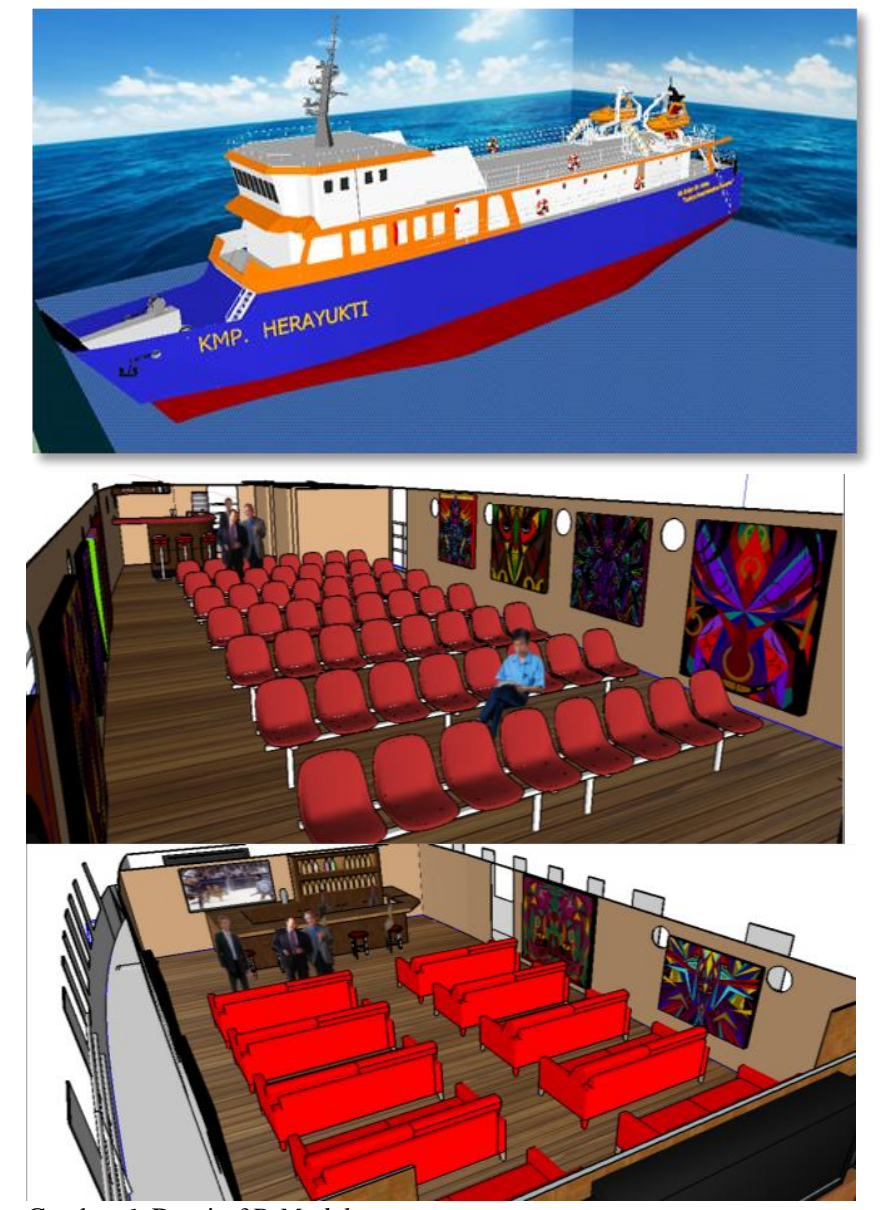

Gambar 6. Desain 3D Model

\section{UCAPAN TERIMA KASIH}

Penulis mengucapkan terima kasih kepada Kantor Kesyahbandaran dan Otoritas Pelabuhan Kelas IV Padangbai Bali yang telah memberikan data penumpang dan kendaraan dari Pelabuhan Padangbai menuju Pelabuhan Nusa Penida pada tahun 2014 - 2016 dan kepada segenap keluarga yang telah memberikan motivasi dalam menyelesaikan penelitian ini.

\section{DAFTAR PUSTAKA}

[1] K. K. B. Perekonomian, Perkembangan Pelaksanaan MP3EI Koridor Ekonomi Bali dan Nusa Tenggara. Jakarta: Kementrian Koordinator Bidang Perekonomian, 2013.

[2] B. Prihartono, Pengembangan Tol Laut Dalam RPJMN 2015-2019 dan Implementasi 2015. Jakarta: Kementrian Perencanaan Pembangunan Nasional, 2015.

[3] K. Perhubungan, Tatacara Petunjuk Pengamanan (securing) Kendaraan di Kapal. Jakarta: Kementrian Perhubungan, 2016.

F. Rohmadhana, "Analisis Teknis dan Ekonomis Konversi Landing Craft Tank (LCT) Menjadi Kapal Motor Penyeberangan (KMP) Tipe Ro-ro untuk Rute Ketapang (Kabupaten Banyuwangi) Gilimanuk (Kabupaten Jembrana),” J. Tek. POMITS, 2016. 